\title{
The Prosody of Split and Glued Verb Constructions in Chácobo (Pano)
}

\author{
ADAM J. TALLMAN \\ The University of Texas at Austin ${ }^{1}$
}

\section{O Introduction}

Chácobo is a southern Panoan language of the northern Bolivian Amazon. ${ }^{2}$ As with other Panoan languages, the verb is polysynthetic and highly suffixing (cf. Loos 1999 and Fleck 2013 for overviews of the family). However, the verb complex can be divided into two types of constructions, one which occurs with all morphemes bound together ("glued" construction), and another which is split into two pieces interrupted by a subject noun phrase ("split" construction). In this paper I give a brief description of the alternation between what I call "glued" and "split" constructions in the verb complex. I provide a unified description of the verbal prosody in the sense that the analysis does not require different principles of prosodic word construction depending on the construction type. I argue that much of Chácobo morphology consists of prosodic clitics in the sense of Selkirk (1996) and Anderson (2005). In addition to assuming that Chácobo has internal and free prosodic clitics, it also constructs prosodic words from clitic combinations without a stem.

This paper is based on 5 months of fieldwork with the Chácobo in Alto Ivón, Riberalta and Las Limas in the summers of 2011, 2012 and 2013, and is part of a larger project that aims to write a descriptive grammar of the language (cf. Fleck 2013 for an overview of the documentation efforts on Panoan languages).

\section{The synthetic Panoan verb}

\subsection{Morphosyntax}

\footnotetext{
${ }^{1} 1$ = 'first person'; 2 = 'second person'; 3 = 'third person'; $\mathrm{ACC}=$ 'accusative'; AGAIN = 'again'; $\mathrm{ALL}=$ 'all'; ALONE $=$ 'alone'; APPL = 'applicative'; ALLDAY = 'during the entire day'; BEN = 'benefactive'; $\mathrm{DEM}=$ 'demonstrative'; CAUS = 'causative'; $\mathrm{CMPL}=$ 'completive'; CRAS = 'crasternal, tomorrow'; ERG = 'ergative'; $\mathrm{HAB}=$ 'habitual'; HEST $=$ 'hesternal'; INCL $=$ 'inclusive'; IMPER = 'polite imperative'; IMPER2 = 'command imperative'; $\mathrm{NEG}=$ 'negative'; $\mathrm{NMLZ}=$ 'nominalization'; $\mathrm{NOW}=$ 'now, immediate present'; $\mathrm{PL}=$ 'plural'; RECPAST $=$ 'recent past'; REMPAST $=$ 'remote past'; REL = 'relative clause marker'; $\mathrm{SG}=$ 'singular'; TOP = 'topic'; $\mathrm{TR}=$ 'transitive'; TRUN = 'truncation'; $v=$ 'light verb'; $\mathrm{PWd}=$ 'prosodic word; $\mathrm{PPh}=$ 'phonological phrase'; $\mathrm{H}=$ 'high tone'; $\mathrm{M}=$ 'mid tone'; $\mathrm{L}=$ 'low tone'.

${ }^{2}$ Many thanks go to my Chácobo consultants and teachers Caco Moreno, Gere Ortiz, Pae Chávez, Mahua Chávez, Milton Ortiz, and Mario Chávez. I would also like to acknowledge the helpful comments I received on this paper from Megan Crowhurst and other BLS participants. Additional thanks go to Antoine Guillaume for insightful comments on this paper. All mistakes are my own.
} 
Panoan languages and languages of Amazonia generally are described as having syntax-like morphology which includes variable morpheme ordering, affix reduplication and a high degree of compositionality (Guillaume 2010: 20) for Cavineña; Payne (1990: 227-230) for Yagua and Capanahua; Aikhenvald (2012: 134-5) for Amuesha, Urarina and Tariana). Chácobo is no exception in this regard.

(1) VARIABLE MORPHEME ORDERING

a. hābà-tìk $k^{\prime}-k \grave{t}$

run-AGAIN-CMPL

'He ran again.'

b. hābà-tīkì-yámà-kì

run-AGAIN-NEG-INCL

c. hābà-yámà-tìkt́-kì

run-NEG-AGAIN-INCL

'He doesn't run again.'

(2) REDUPLICATION

a. kā-yámà-yámà-kì

go-NEG-NEG-CMPL

'He didn't go. (It's impossible that he went.)'

b. $\quad k \bar{a}$-tápì-tápì-kì

go-FAST-FAST-CMPL

'He went fast (without thought).'

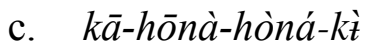

go-COME-COME-CMPL

'He came (without rest).'

d. mí-à tsāyà-fārì-fàrí-kì

2SG-ACC see-CRAS-CRAS-INCL

'I will see you (the day after tomorrow).'

Chácobo seems to go even further than other Amazonian languages in having syntax-like properties in its morphology. The verb complex can be divided into two construction types. One construction corresponds to a canonical Panoan verb, with all functional material bound to the root (the "glued" construction). The other construction "splits" the verb complex into two pieces. In the "split" verb construction the verb stem and some derivational material occur discontinuous with the final TAM affixes, separated by a subject noun phrase. ${ }^{3}$ An example of the "glued"

\footnotetext{
${ }^{3}$ Chácobo has an ergative alignment split by noun type (full noun or pronoun), aspect and word order (cf. Córdoba et al. 2012). The ergative is marked by an $\mathrm{H}$-tone being docked to the final syllable on the right-most edge of the
} 
construction is given in (3a) and the "split" construction in (3b) (the pieces of the verb complex are underlined) (more detail is given in $\S 2$ ).

(3) a. GLUED CONSTRUCTION

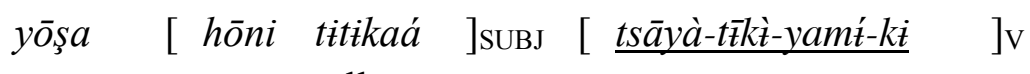
woman man tall.ERG see-AGAIN-HEST-CMPL

'The tall man saw the woman again yesterday.'

b. SPLIT CONSTRUCTION

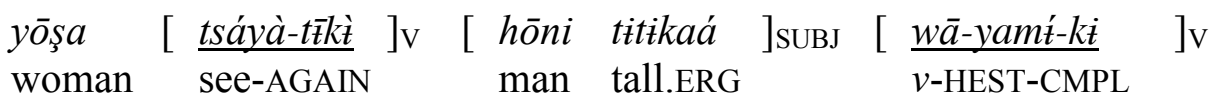

'The tall man saw the woman again yesterday.'

In Panoan languages the synthetic verb complex usually corresponds to the domain of the prosodic word (Fleck 2003 for Matses; Elias-Ulloa 2006, 2011 for Shipibo-Konibo; Zariquiey 2011 for Kashibo-Kakataibo). The split construction clearly complicates this analysis since prosodic domains such as the PWd cannot be discontinuous (e.g. Selkirk 1984, Nespor \& Vogel 1986). Furthermore, the distribution of H-tones in the verb complex, the primary markers of prominence, suggests that an analysis where the entire verb complex is one PWd is problematic for reasons described in the following section.

\section{$1.2 \quad$ Prosody}

An issue that is addressed less in the literature on the purportedly exotic characteristics of Amazonian morphosyntax is that of prosodic organization (Russell 1998 for a critique). In Hyman's $(2006,2011)$ word prosodic typology, culminative and obligatory prominence over a word is one of the defining properties of a stress system, but Chácobo does not obviously conform to this. Prominence (realized as surface $\mathrm{H}$ tones) are not always culminative even when the same morphemes are involved. Different orderings of tiki-AGAIN tapi-FAST can result in one (4a) and two (4b) high tones in the verb complex.

(4) a. CULMINATIVE H-TONE

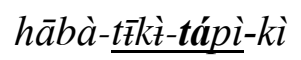

run-AGAIN-FAST-INCL

b. NON-CULMINATIVE H TONE

hābà-tápi-tì kí-ki

run-FAST-AGAIN-CMPL

'He doesn't run again.'

noun phrase (Valenzuela \& Iggesen 2007). In (3) the high tone is docked to the adjective tikikaá 'tall', however, if the word order was reversed the head of the noun phrase honi would receive this high tone. 
In the following analysis I argue that such properties require parsing more than one PWd over the verb complex. The analysis is furthermore necessitated because of the split verb construction described above. Furthermore, I analyze the morphology of the verb complex as composed of prosodic clitics (cf. Selkirk 1996, Anderson 2005). This paper is partly concerned with characterizing what types of prosodic clitics need to be in the verb complex. In $\S 2$ I give an overview of the morphosyntax of the verb complex. $\$ 3-4$ then gives a brief overview of the suprasegmental properties of Chácobo; $\S 3$ focuses on the interaction between metrical and tonal properties adopted in the current analysis; $\$ 4$ focuses on describing the basic suprasegmental properties of the verb complex. $\S 5$ gives a prosodic analysis of the phenomena described in the previous section. $\S 6$ gives an overview of the paper and emphasizes areas of future research.

\section{The clitic based morphology of the Chácobo verb}

The verb complex in Chácobo can be roughly schematized as in (5) below. Bold positions indicate slots that are obligatorily filled. A verb must contain minimally a root and a final aspect marker (Zingg 1998).

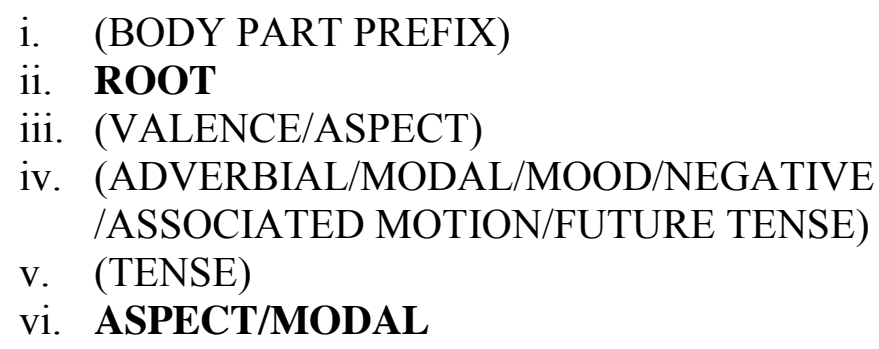

As we will see, the situation is considerably more complex than what is given in (5), especially when we consider the split verb construction and variable morpheme ordering (a more detailed template is given below).

\subsection{Split and glued verb constructions}

\subsubsection{Split by noun phrases}

As stated in $\S 1$, Chácobo verb complexes can be divided into two constructions; one is a split construction and the other is a glued construction. In the split construction the verb root and some valency changing material appear discontinuous with final TAM enclitics. When the verb construction is transitive, a morpheme $w a$ - is bound to the TAM material. ${ }^{4}$ Examples contrasting the intransitive-transitive and glued-split constructions are given below.

\footnotetext{
${ }^{4}$ Alternatively $w a$ - could be regarded as a carrier and host of the TAM material.
} 
(6) INTRANSITIVE

a. INTRANSITIVE GLUED

[àdáy $]_{\mathrm{NP}}[k \bar{a} \text {-yámà-tìkí-kì }]_{\mathrm{V}}$

Adam go-NEG-AGAIN-CMPL

'Adam didn't go again.'

b. INTRANSITIVE SPLIT

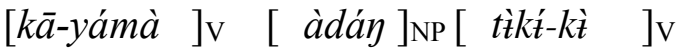

go-NEG Adam AGAIN-CMPL

(7) TRANSITIVE

a. TRANSITIVE GLUED

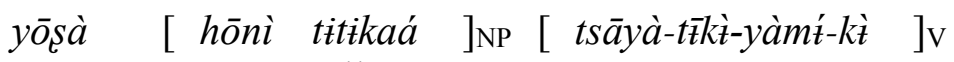

woman man tall-ERG see-AGAIN-HEST-CMPL

b. TRANSITIVE SPLIT

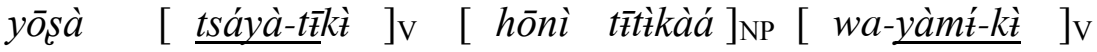

woman see-AGAIN man tall-ERG v-HEST-CMPL

'The tall man saw the woman again yesterday.'

The split construction can only contain a subject noun phrase between the two pieces of the verb complex. It is not obviously an instance of noun incorporation because the noun phrase can contain full relative clauses and only the subject can intervene (cf. Mithun 1986). ${ }^{5}$ The alternation between glued and split constructions has no obvious semantic function (although it may have an information structure function). The wa-could be regarded as a dummy morpheme and has no obvious semantic function in the split constructions above. The wa-cannot appear when the construction is glued. From this point on I refer to the root as stranded from its aspectual marker, and the aspectual marker as stranded from the root in the split construction.

\subsubsection{Split by pronouns}

Descriptions of Chácobo have made reference to "bound pronouns" (Zingg 1998, Córdoba et al. 2012). Chácobo pronouns follow a nominative-accusative alignment. "Bound pronouns" occur between the stem and the final aspect marker. Only subject pronouns (A and S) can surface as "bound pronouns". ${ }^{6}$ Bound pronouns occur in free alternation with preverbal non-bound pronouns. Examples are given below with the "bound pronoun" constructions occurring in the examples in (7-9b).
a. $\bar{t} \quad \dot{a} / \grave{l}-k \grave{t}$
1SG bathe-CMPL
'I bathed'
b. $\quad \bar{a} \int \hat{\imath}-P \dot{\boldsymbol{t}}-k \dot{\boldsymbol{t}}$
bathe-1SG-CMPL
'I bathed'

\footnotetext{
${ }^{5}$ No Panoan languages contain noun incorporation to my knowledge, although they do contain instances of bodypart incorporation which has an adverbial or verbal classificatory function (cf. Fleck 2006).

${ }^{6}$ They also occur in nominative shape without an accusative marker $-a$.
} 

a. $\quad \bar{t} \quad t f u ́ s \bar{a}-k \grave{t}$
$1 \mathrm{SG}$ destroy.TR-CMPL
'I destroyed it.'
b. $\quad t / \bar{u} s \grave{c}-2 \dot{t}-w a ̀-k \grave{t}$
destroy.TR-1SG- $v$-CMPL
'I destroyed it.'

Although "bound pronoun" constructions have been described separately from the split construction, they are clearly just instantiations of it (with a pronoun splitting the verb complex instead of a full NP). The verb complex is split in the exact same position, and a $w a$-is inserted in the same environment. The distributional facts are the same as the alternation between the glued and split construction. The orthographic representation commonly given as in (7-8) is somewhat misleading. The word segmentation below could be applied to bound pronoun constructions where the root is separated from the pronoun.
a. $\quad \dot{a} \hat{\imath} \quad P^{\prime}=k \grave{t}$
bathe $1 \mathrm{SG}=\mathrm{CMPL}$
b. tfusa Pi $w a-k \dot{t}$
destroy $1 \mathrm{SG} v$-CMPL
'I bathed'
'I destroyed it.'

The split construction poses interesting distributional problems for the ordering of verbal morphemes in the verb complex. Panoan languages have a highly complex templatic and suffixal verbal morphology. Which side of the split complex a morpheme occurs on (left, right or both) is a distributional problem for the description of the verb in Chácobo. This issue is briefly discussed in the following section.

\subsection{Semi-templatic morphology: Fixed and variable orderings}

\subsubsection{Fixed affix orderings}

Recall from $\S 1$ that some affixes in Chácobo can occur in "variable orderings". This is not true of all morphemes, however. Some occur in a fixed order. Examples in (11) demonstrate that -mis MAL.HAB and -ma CAUS occur in a fixed order with respect to one another. Examples in (12) demonstrates that the final tense and aspect markers occur in a fixed ordering with respect to one another and cannot be interrupted by any other morphemes. (11d) where causative occurs before the habitual applicative is ungrammatical.
MAL.HAB-CAUS
a. t $\int \bar{a} n i-m a ́-k \dot{t}$
speak-CAUS-CMPL
b. $\quad t \int \bar{a} n \grave{i}-m i ́ s-k \grave{t}$ speak-MAL.HAB-CMPL
'He made him speak.'
'He used to speak badly on behalf of someone.'

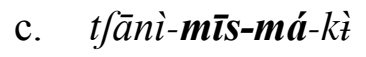

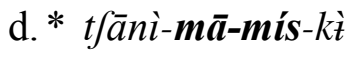
speak-MAL.HAB-CAUS-CMPL speak-CAUS-MAL.HAB-CMPL
'He used to make someone speak poorly on behalf of someone.' 
TENSE-ASPECT

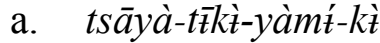
b. *tsaya-yami-tiki-ki
see-AGAIN-HEST-CMPL
see-HEST-AGAIN-CMPL

'He saw him again yesterday.'

c. **tsaya-ki-yamit

see-CMPL-HEST

\subsubsection{Variable affix orderings}

A larger class of morphemes can be variably ordered. An example is the associated motion morpheme -hónà- COME.INTR.

X-ASSOCIATED MOTION $\sim$ ASSOCIATED MOTION-X

a. häbà-tīkì-hòná-kì

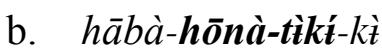

rUn-AGAIN-COME.INTR-CMPL

run-COME.INTR-AGAIN-CMPL

'He ran (coming in this direction).'

\subsubsection{Templatic morphology and the split construction}

All morphemes that occur in a fixed order (described in \$2.31) occur bound to one side and only one-side of the verb complex when it is split. An example of this is with the tense morpheme yami- HEST. Tense morphemes never occur with the root in the split construction. An example of this is given in (13).
a. tsāyà hòní wā-yàmí-kì
see man.ERG $v$-HEST-CMPL
'The man saw him yesterday.'
b. **tsaya-yami honi wa-ki see-HEST man $v$-CMPL

The morpheme ma- CAUS described in $\$ 2.3 .1$ mirrors yami- HEST in only being able to occur on the left verbal piece bound to the stem in the split construction.
a. tsáyà-mā hòní wā-kì
see-CAUS man.ERG $v$-CMPL
b. **tsāyà hóní wā-má-kì see man.ERG $v$-CAUS-CMPL

'The man made him see someone.'

In contrast all variably ordered morphemes as described above can occur on either side of the split verb complex. An example is given in (15) with the associated motion morpheme binaCOME.TR.
a. tsáyà-bīnà hòní wā-kì see-COME.INTR Man.ERG $v$-CMPL
b. tsáyà hòní wā-bìná-kì 'The man saw him (while coming this direction).' see man-ERG $v$-CAUS-CMPL 
A generalization emerges concerning the relationship between variable morpheme order and the distribution of morphemes in the split construction. If a morpheme occurs with a fixed templatic structure it will be bound to one side or the other in the split construction. If a morpheme occurs with variable ordering it can occur on either side of the verb complex in the split construction. Another important point is that variably ordered morphemes cannot be interspersed between fixed ordered morphemes. The fixed ordered morphemes occur fixed in relation to either the root or the obligatory final aspect marker which define the periphery of the verb complex. In other words, variable ordering of morphemes occurs towards the middle of the verb complex, where the split occurs.

This situation can be represented in the template given below. Positions in bold (positions 1 and 10) are obligatory, optional slots are in parentheses (positions 2, 3, 6,9 and 11) and optional, recursive and variably ordered morphemes occur in curly brackets (positions 5 and 8). Notice that the latter morphemes flank the position of the subject noun phrase in the split construction.

The distributional facts of the Chácobo verb are complex and are not taken up here in detail (cf. Tallman in prepb for a more detailed overview). However, the preceding discussion allows us to make one important descriptive generalization concerning the relationship between the split verb construction and variable affix ordering. Fixed templatic style morphology, the type that is associated with morphological word-hood (cf. Dixon \& Aikhenvald 2002), breaks down where the verb complex can be split by a subject.

Many criteria for morphological word-hood converge towards a bipartite structure. ${ }^{7}$ The criterion of fixedness of order (Mugdan 1994: 2552, Dixon \& Aikhenvald 2002: 19) would split the verb complex where variably ordered morphemes occur. The criteria of movability and separability (Boas 1911: 30) would split the verb complex where a subject noun phrase can occur. The minimum free-form criterion (Bloomfield 1933: 178, Hockett 1958: 168) identify the entire verb complex as the word since the stem and final aspect marker are always obligatory. An interesting question is how the prosody is structured under in relation to such a situation.

\footnotetext{
${ }^{7}$ Tallman (in prepb) gives a more detailed discussion of the criteria for wordhood, affixhood and clitichood in Chácobo.
} 
Figure 1. Morphological template for Chácobo verb

\begin{tabular}{|c|c|c|c|c|c|c|c|c|c|c|}
\hline- & $N$ & $n$ & $\nabla$ & $n$ & 0 & $r$ & $\infty$ & $a$ & 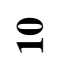 & $=$ \\
\hline $\begin{array}{l}5 \\
0 \\
0 \\
\simeq\end{array}$ & 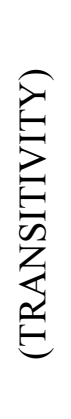 & 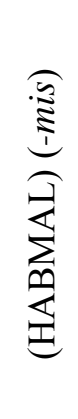 & 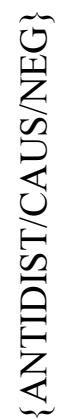 & 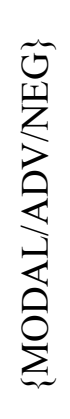 & 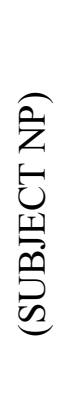 & 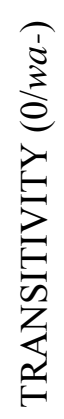 & 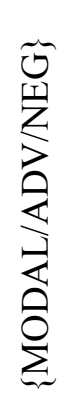 & 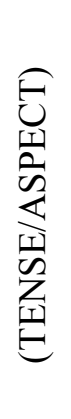 & 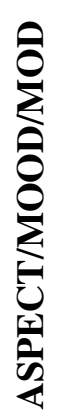 & 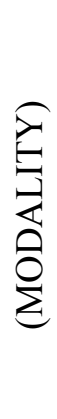 \\
\hline
\end{tabular}

At the same time, by most criteria, Chácobo's verbal morphemes should be regarded as clitics. Most of them do not occur in a fixed ordering with respect to each other, and they display a low level of selection. There are no local morphophonological idiosyncracies between the verbal morphemes. ${ }^{8}$ Even the obligatory final aspect marker does not need to occur attached to the verb root. ${ }^{9}$ A detailed analysis of the morphological status of Chácobo verbal morphology is beyond the scope of this paper. In this paper I am concerned with the status of Chácobo verbal morphemes as prosodic clitics (in the sense of Selkirk 1996 and Anderson 2005). This is taken up in $\S 5$ after a review of the prosodic facts in the verb complex is given.

\section{$3 \quad$ Metrical and tonal analysis}

The prosodic domains of interest involve suprasegmentals. This section provides a basic description of the relationship between tonal and metrical categories in the language (cf. Hyman 2006 for a typology). The basics of metrical and tonal phenomena are easier to establish with nouns than with verbs. The reason for this is that verbs are morphologically complex and thus it is difficult to isolate the metrical and tonal categories of interest. In this paper, therefore, I introduce the analysis with nouns.

\subsection{Suprasegmentals}

Nouns can be distinguished by their pitch shape. By "pitch shape" I mean pattern of relative pitch variation. The identification of "surface pitches" in this paper makes no commitment

\footnotetext{
${ }^{8}$ According to Zwicky and Pullum (1983: 505) morphophonological idiosyncracies are a criterion against clitichood in host-clitic combinations and an argument for an affixal treatment. Local morphophonological idiosyncracies are almost non-existent in Chácobo, with one except between a postverbal subject pronoun and the incompletive marker $-k i$ INCL (-ki INCL $+\dot{t} a$ 1SG.ACC -> -kía) (Iggesen 2006).

${ }^{9}$ See Haspelmath (2011) for a critical review of wordhood criteria in the literature. Haspelmath (2011) argues that there is no clear and non-problematic boundary between words, clitics and affixes and that authors apply criteria selectively to the needs of their particular analyses.
} 
concerning the underlying and contrastive tones of the language. In particular, I will argue that $\mathrm{M}$ tones are not contrastive. L tones are marginally contrastive, but this can only be shown when we move onto the verb complex in $\S 4$.

(17) HL surface tones
a. mípò 'dust'
b. tsístì 'charcoal'
c. tfî́kà 'little, cuckoo'
d. Pískò 'green-winged saltador'

(18) LH surface tones
a. nàtí 'flu'
c. finó 'monkey'
b. nòti 'canoe'
d. bàkí 'child'

(19) HML
a. tí pōkò 'goiter'
b. má pārì 'bread'
c. bá kōşò 'foam'
d. wíftìmà 'star'

(20) MHL
a. şō 'kóbò 'children'
b. $k \bar{a}$ 'napà 'lightning'
c. kā'mánò ' 'jaguar'
d. $\beta \bar{a} \cdot k i j i \quad$ 'darkness'

\section{(21) MLH}
a. $m \bar{a} \cdot$ 'int $\quad$ 'sand'
c. ì spàrá 'temple of head'
b. pā'?òki 'ear'
d. ş̄òtí 'wind'10

I have found no evidence for a contrastive $\mathrm{M}$ tone. ${ }^{11}$ The reader should keep in mind that a vowel with a $\bar{V}$ on it represents a mid pitch which occurs on metrically strong syllable (cf. n12). Following Prost (1960: 8) I have found some evidence for an underlying L tone, however it is fairly marginal (cf. Tallman 2014 for a more detailed discussion and analysis of nouns). The most important generalization is that an $\mathrm{H}$ tone (or high pitch) is obligatory within the word domain for nouns. In the following I provide a metrical analysis of the suprasegmental phenomena given above.

\subsection{Interaction of metrical stress and tone}

This section does not give a complete description of the metrical rules of Chácobo (Tallman in prepa), but rather describes the general properties of the system necessary for basic background.

\footnotetext{
${ }^{10}$ In prevocalic contexts the first vowel is not lengthened. Sometimes a glottal stop is inserted between the two first syllables in cases such as these (st̃̂̀totí 'wind'). This phenomenon is completely obligatory in the Pacahuara codialect of Chácobo (Ortiz \& Tallman 2012). This topic requires instrumental phonetic investigation.

${ }^{11}$ This is in contrast to a comment made in passing by Shell (1985: 52: n37) concerning the possibility of contrastive $M$ tones existing in the language.
} 
I assume that surface pitch variation encodes prominence. ${ }^{12} \mathrm{H}$ tones and $\mathrm{M}$ pitches are markers of metrically strong syllables and L tones correspond to weak syllables. The analysis conforms to the typological generalizations found in de Lacy $(1999,2002)$. De Lacy (2002) formalizes the cross-linguistic relationship between metrical strength and tone with the tonal prominence hierarchy.

\section{Tonal prominence scale \\ $\mathrm{H}>\mathrm{M}>\mathrm{L}$}

(de Lacy 2002: 2)

I assume that the position of the $\mathrm{H}$ pitch reflects underlying $\mathrm{H}$ tone in Chácobo and that all other surface tones are predictable from the position of this underlying tone. I argue that Chácobo has the following metrical inventory and tone mapping rules (cf. Tallman in prepa for more details with a slightly different analysis).

(23) Trochaic and iambic feet (' $\sigma \sigma, \sigma \sigma$ '), and a H-Tone monosyllabic foot (' $\sigma$ ) (cf. Tallman 2014, Gonzalez 2014)

(24) Stress-to-H Tone rule:

A metrically strong syllable is mapped to an underlying $\mathrm{H}$ tone.

(25) Pitch-to-Stress rules:

a. Map M pitches onto all remaining (those that do not have an $\mathrm{H}$ tone) strong syllables in a word (or prosodic domain)

b. Map L pitches/tones onto all remaining syllables.

If one considers the form below, and we assume bisyllabic trochees and monosyllabic feet with one H-Tone syllable (in conformity with Hayes 1995: 71), surface tones and pitches are mapped in the following manner (where $\mathrm{s}=$ head, and $\mathrm{w}=$ non-head of a foot).

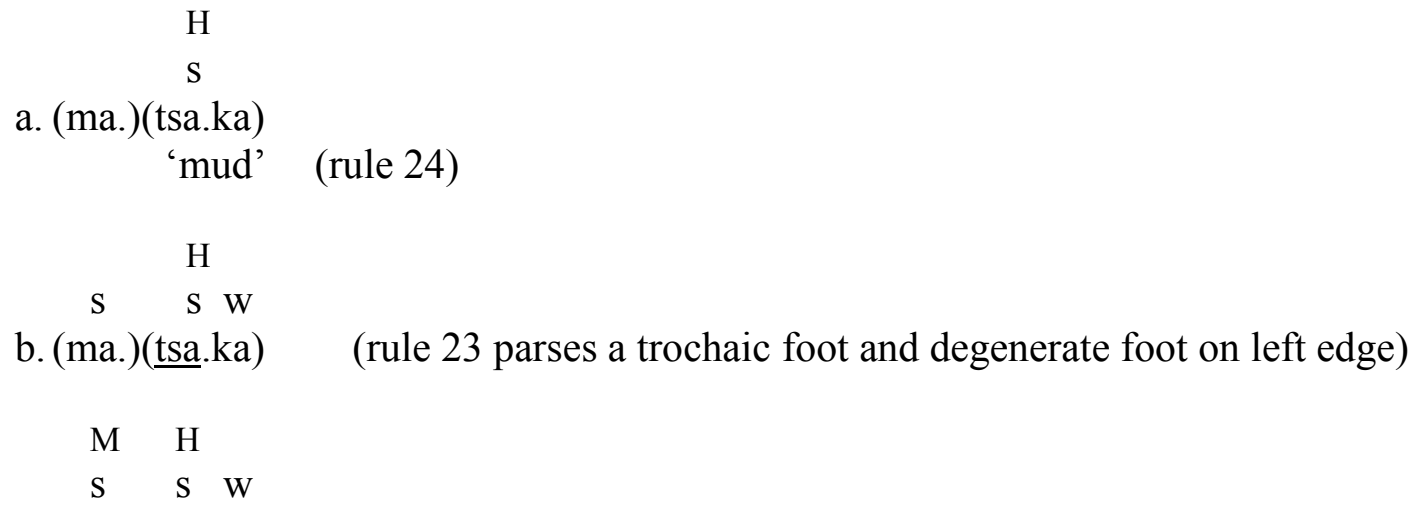

\footnotetext{
${ }^{12}$ Research is underway to determine to what extent pitch is the only marker of prominence. Since the current study is based on impressionistic data, it is highly likely that other correlates (such as duration and intensity) play a part in marking metrical prominence.
} 

c. (ma.)(tsá.kà)
(rule 25a maps M pitch onto stressed syllable)
M H L
S S W
d. (mā'.)(tsá.kà) (rule 25b maps L tone/pitch onto unstressed syllable)

In the following section I give a description of Chácobo verbal prosody.

\section{Chácobo verbal prosody}

This section gives a description of prosody in Chácobo. $\S 4.1$ describes the different types of verbal morphemes based on their prosodic behavior. $\S 4.2$ discusses the behavior of stems. $\S 4.3$ gives an overview of culminativity, obligatoriness and metrical lapses in the verb complex.

\subsection{Prosodic classification of morphemes}

Verbal morphemes divide into at least three different types. These are defined in (28). ${ }^{13}$

(27) a. H-tone morphemes: Require an $H$ tone on the same syllable no matter what the prosodic or phonological context (e.g. -yáma- NEG, -tápi- FAST).

b. Toneless morphemes: Have multiple (more than one) prosodic allomorphs. Prosodic shapes are malleable, partly conditioned by metrical context (-tiki- AGAIN, -kara- DUB).

c. L-tone morphemes: Cannot occur with an $\mathrm{H}$ tone. They have prosodic allomorphs that contain only L and M surface pitches (-tsa- NOW.TR, -tsi- NOW.INTR, $w a$ - TR).

The clitic -yáma NEG is an example of an H-tone morpheme. It always has an HL surface shape no matter what its position is.

(29) H-TONE MORPHEME: -yámà NEG (obligatorily requires HL pattern: H-Tone morpheme)

a. hābà-tīk̀̀-yámà- $k \grave{t}$

run-AGAIN-NEG-CMPL

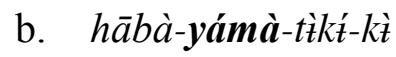

run-NEG-AGAIN-CMPL

'He doesn't run again.'

H tones never surface on L-Tone morphemes. -tsi- NOW.INTR is an example of an L-tone morpheme. As we will see, the default position for $\mathrm{H}$ tone is the penultimate syllable of the verb complex. However, no H-tone falls on -tsi- NOW.INTR despite the fact that it occurs in penultimate position.

\footnotetext{
13 The names of the morpheme types are meant to signal their underlying prosodic properties (these are discussed in $\S 5)$. This section simply describes what these properties are without providing an analysis.
} 

a. ká-tsi-ki
go-NOW.INTR-INCL
'He goes now.'
b. tfáni-tsi-ki
'speak-NOW.INTR-INCL
'He speaks now.'

The surface pitch shape of toneless morphemes is highly variable. Toneless morphemes can

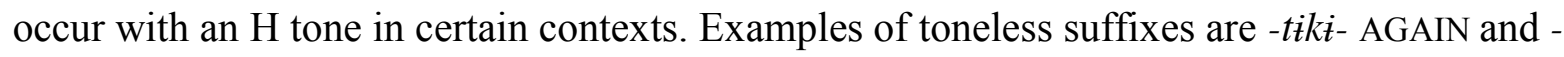
$k a r a-$ DUB. Notice that in (31a) -tiki- AGAIN occurs with an LH tonal/pitch shape [tìk'́] and -karaDUB occurs with an ML shape [kārà], while in (31b) the situation is reversed when the order of the morphemes is reversed.

\section{(31) TONELESS MORPHEMES \\ a. hābà-kāà $\mathbf{a}-\mathbf{t} \boldsymbol{k} \boldsymbol{k}-k \grave{t}$ \\ run-DUB-AGAIN-CMPL \\ 'He probably ran again.' \\ b. hābà-t̄̄kì-kàrá-kì \\ run-AGAIN-DUB-CMPL \\ 'He probably ran again.'}

\subsection{The prosodic behavior of roots versus affixes}

The previous section demonstrated that if there is allomorphy in the verb complex it is based completely on tonal/metrical variation. Roots are exceptions to this. In previous literature on Chácobo it has been noted that sometimes verb stems insert a vowel. Córdoba et al. (2012) described this as occurring in "bound pronoun" constructions (word-segmentation is from Córdoba et al. 2012).
a. $p i>p i i$
$p i i-2-\dot{t}-w a-k \dot{t}$
b. $\quad a>a a$
eat-EP-1 SG- $v$-CMPL
$a a-?-\dot{t}-w a-k \dot{t}$
'I ate it.'
do-EP-1SG- $v$-CMPL
'I did/ate/drank it.'

As argued in $\S 2$, "bound" pronouns constructions are instantiations of split verb constructions with an intervening pronoun rather than a full noun phrase. The segmentation of word boundaries could equally well have been as follows. 

a. pii $P \dot{i} w a-k \dot{t}$
eat $1 \mathrm{SG} v$-CMPL
'I ate it.'

b. $\quad$ aa $2 \dot{i}$ wa-ki

do 1 SG $v$-CMPL

'I did/killed/drank it.'

Vowel epenthesis on the root occurs when a monosyllabic verb root is stranded away from any verbal morphemes. The examples in (34b) and (34d) have vowel epenthesis while in examples (34a) and (34c) it is prohibited. ${ }^{14}$ The vowel epenthesis is demonstrated through the position of the variably ordered clitic -kas- DES.
go-DES man=CMPL
'The man wanted to go.'
a. $\quad \boldsymbol{k} a \grave{a}-k a ́ s \quad h o ́ n \bar{\imath}=k \grave{t} \quad(* k a a)$
b. káà hónì kás-kì $\quad(* k a)$
go man DES-CMPL
'He wanted to go.'
c. pì-kás honí=ki (*pii)
eat-DES man.ERG $=\mathrm{CMPL}$
'He wanted to eat it.'
d. piì hòní kás-kì (*pi) eat man.ERG DES-CMPL 'He wanted to eat it.'

Vowel epenthesis seems to be driven by constraints on the minimal size of content words.

Minimal bisyllabicity of PWd is well-motivated for nouns (Tallman in pressa). Roots constitute a separate prosodic class from other verbal morphemes; they are the only morphemes that undergo vowel epenthesis. Stranded aspect markers for instance do not lengthen their vowels.

\subsection{Generalizations in the verb complex}

\subsubsection{Obligatory $\mathrm{H}$ tone}

Every verb complex has at least one $\mathrm{H}$ tone. The domain for this obligatory $\mathrm{H}$ tone can be made more specific, however. With one exception to be discussed below, H-tone is obligatory in the last two verbal morphemes of the verb complex (x-ASP where X refers to any verbal morpheme).

OBLIGATORY H TONE IN X-ASP WITH H-TONE MORPHEME

a. hābà-tīkì-yámà-kì

run-AGAIN-NEG-INCL

'He doesn't run again.'

b. wāà̀-bōnà-wí

steer-GO.TR-IMPER2

'Steer (the boat), while moving!'

\footnotetext{
${ }^{14}$ The issue of whether H-tone epenthesis applies in stranded verbs is an important empirical question that still needs to be tested in the field. At this point I only have a few examples that seem to suggest that such epenthesis occurs.
} 


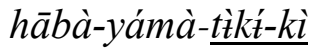

run-NEG-AGAIN-INCL

'He is not running again.'

There are two exceptions to this generalization. If the penultimate morpheme is an L-Tone morpheme, an obligatory $\mathrm{H}$ tone does not occur in this domain. -wa for instance is an L-tone morpheme. No H-tone occurs on this syllable.

$$
\begin{aligned}
& \text { tsáyà hòní } \underline{w a-k i ̀} \\
& \text { see man.ERG } v \text {-CMPL }
\end{aligned}
$$

'The man him.'

The other exception to $\mathrm{H}$ tone obligatoriness in the final two morphemes is when the verb complex is split and an aspect marker is stranded occurring right-adjacent to a subject DP.

$$
\begin{aligned}
\mathrm{ROOT} \quad \mathrm{DP} & =\mathrm{ASP} \\
\text { hàbá }[\text { inàkà }=b \grave{o}]_{\mathrm{DP}} & =k \grave{t} \\
\text { run } \operatorname{dog}=\mathrm{PL} & =\mathrm{CMPL}
\end{aligned}
$$

'The dogs ran.'

\subsubsection{Violations of culminativity of $\mathrm{H}$ tone}

When an H-Tone morpheme occurs outside the two morpheme window described above an apparent violation of culminativity occurs. Examples are given in in (39).
a. hābà-yámà-tìkí-kì
run-NEG-AGAIN-INCL
'He does not run again.'
b. hābà-tápì-tìkí-kì
run-FAST-AGAIN-INCL
'He runs quickly again.'

\subsubsection{Default trochee on right edge}

As we have seen one way of analyzing the surface tonal patterns is by assuming right-to-left assigned trochees. This can be seen the most clearly with all toneless morphemes.
a. $\quad h a \bar{a} b \grave{a}-t \bar{t} k \grave{t}-b \bar{a} P i n a ́-k i ̀$
run-AGAIN-ALLDAY-INCL 
b. M L ML M L $\mathrm{H}$ L

(ha.ßa.)(ti.ki.)(ba.Pi.)(na.ki.)

'He runs again all day.'

When the amount of syllables in the last two morphemes is uneven, then there is a metrical lapse between the final two morphemes and the rest of the verb complex (underlined below). The tone tier and metrical parse is given in (41b).
a. hābà-kārà-tìktí-kì
run-DUB-AGAIN-CMPL
b. M L M L L H L (ha.ßa.)(ka.ra.)tì. (kí.kì)
'He probably ran again.'

The next section gives a prosodic analysis of clitics in Chácobo.

\section{$5 \quad$ Prosodic analysis of Chácobo clitics}

This section addresses what type of prosodic analysis should be used in order to account for the generalizations given in $\S 4$. Here I address the structure of the prosodic words $(\mathrm{PWd})$ and phonological phrases (PPh) and their suprasegmental (metrical and tonal) properties. I argue that the following types of prosodic clitics are present in Chácobo (Selkirk 1996, Anderson 2005).

a. Internal Clitic: PPh

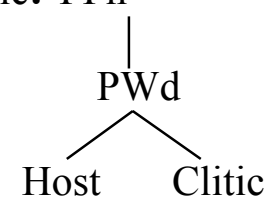

b. PWd Clitic: $\quad \mathrm{PPh}$

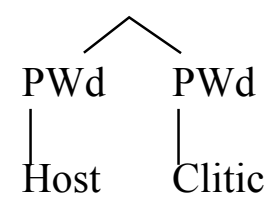

c. Free Clitic:

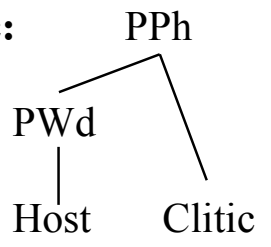

In addition to these prosodic clitics the following analysis also assumes that some verbal morphemes can be differentially prosodized as hosts or clitics. In Selkirk (1996) clitic morphemes are associated with (or equated with) functional morphemes. For Chácobo, however some functional morphemes must also be coded as lexical items in order to account for the 
prosodic facts and, in particular, the fact that combinations of functional morphemes construct a PWd. As we will see this assumption allows us to account for the prosody of the stranded aspectual marker.

\subsection{Underlying tones and prosodic domains}

One way of capturing the different prosodic classes of verbal morphemes is by assuming that they have the following underlying specifications. The names of the morphemes introduced in $\S 4$ foreshadow the analysis given to these morphemes.

(43) a. H-tone morpheme lexical representation: Contains an underlying $\mathrm{H}$ tone; e.g. -yáma NEG, -tápi FAST, -wí IMPER2

b. Toneless morpheme lexical representation: Contains no underlying tone; e.g. -kara DUB, -pari FIRST, -tiki AGAIN, fari- CRAS

c. L-tone morpheme lexical representation: Contains an underlying L tone; e.g. -tsi NOW.INTR, -wà v (light verb)

The following properties define PWd and $\mathrm{PPh}$. Notice that, in the current analysis, culminative and obligatory $\mathrm{H}$-tone is a property of the right-most $\mathrm{PWd}$ in PPh. Obligatory H-tone is actually a property of $\mathrm{PPh}$ rather than $\mathrm{PWd} .^{15}$
a. Domain of Minimal bisyllabicity, domain of right-to-left default trochees
$\boldsymbol{P W d}$ : Constructed over the STEM and/or the right edge of the verb complex; X-ASP.

\section{b. Domain of H-tone in right-most PWd \\ $\boldsymbol{P P h}$ : The left edge is the ROOT, the right-edge is the entire sentence.}

The following rules apply to impose the conditions of the domains when they are not satisfied by the underlying representations of the morphemes that are contained within them. Thus when $\mathrm{PWd}]_{\mathrm{PPh}}$ or the right-most $\mathrm{PWd}$ in $\mathrm{PPh}$ does not contain an $\mathrm{H}$ tone, H-Tone Epenthesis applies in (45). When a PWd is not bisyllabic, vowel epenthesis applies as in (46).

(45) H-Tone Epenthesis (HTE): Insert an H tone onto the right-most metrically strong syllable in $\mathrm{PWd}]_{\mathrm{PPh}}$, if there are no $\mathrm{H}$ tones in this domain underlylingly.

Vowel-Epenthesis (VE): Insert vowel $(\mathrm{C}) \mathrm{V}_{1}>(\mathrm{C}) \mathrm{V}_{1} \mathrm{~V}_{1}$. Apply to $\mathrm{PWd}$ if not bisyllabic.

The following sections give more details on the prosodization of clitics in Chácobo.

\footnotetext{
${ }^{15}$ In Selkirk's (1986) analysis of Chi Mwi:ni stress is assigned at the PPh level. Likewise the analysis here assumes that in Chácobo $\mathrm{H}$ tone obligatoriness is really a property about $\mathrm{PPh}$.
} 


\subsection{Stranding the stem: Internal clitics}

Previous research on Chácobo nouns found much evidence for a minimal bisyllabicity constraint (Tallman in pressa). Assuming roots must be inside PWds can account for segmentally based allomorphy in roots (the alternation between monosyllabic and bisyllabic forms in some roots (e.g. $k a \sim k a a$ 'go'). Note that in cases where the stem is not stranded the vowel cannot epenthesize. Only when a monosyllabic verb root occurs detached from any other verbal morphology does epenthesis occur as a last resort as in (47c).

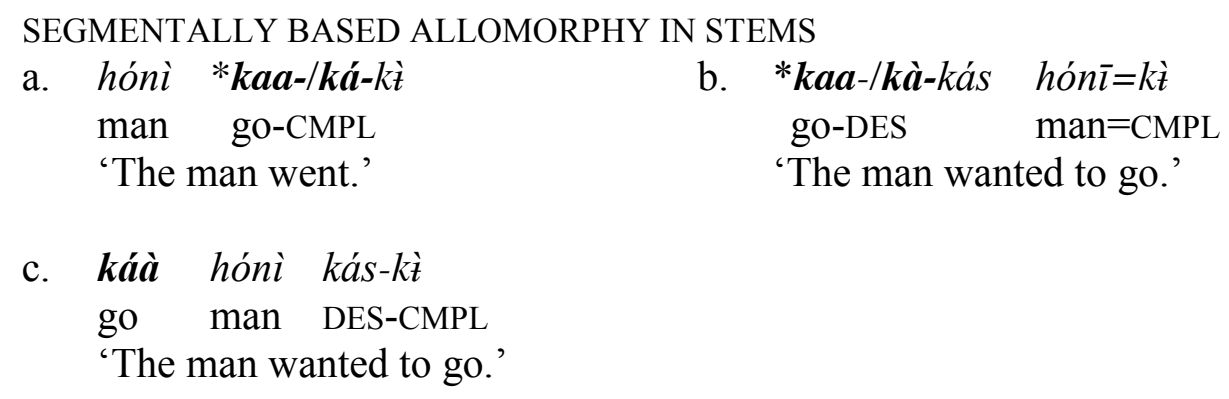

In (47a-b) the stem $k a-$ 'go' surfaces as monosyllabic. This can plausibly be attributed to the fact that the enclitic material attached to it satisfies minimal bisyllabicity for the PWd. The function word is an internal clitic to the stem host.

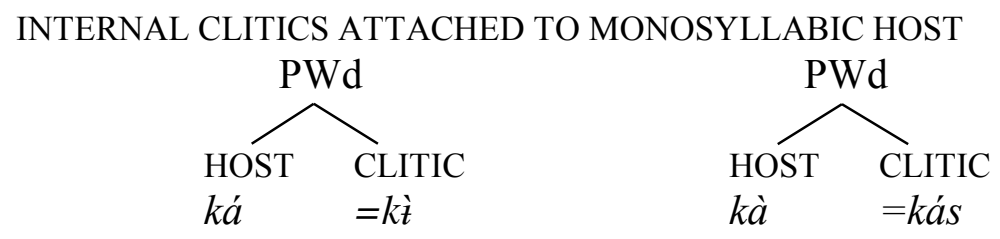

The stem cannot take a noun or DP constituent as its clitic and thus vowel-epenthesis applies as a last resort in $(47 \mathrm{c})$.

\subsection{Right-aligned prosodic words: PWord clitics and clitic hosts}

Recall that the final two suffixes of the verb complex defined a domain of obligatory $\mathrm{H}$ tone, with a few exceptions (these exceptions are taken up in §5.3). If one assumes that a prosodic word is built up from the last two morphemes in the verb complex, this property is accounted for. $\mathrm{H}$-Tone will fall on the penultimate syllable because parsing in PWd is from left to right and the right-most PWd in PPh requires an $\mathrm{H}$ tone. This is discussed in §5.3.1. 
Recall that metrical lapses can occur after the last two morphemes in the verb complex. The current analysis accounts for the precise conditions under which the metrical lapse occurs.

Metrical lapses only occur when the final two enclitics have a syllable count of three. This is also accounted for by assuming a right-aligned PWd clitic. This is discussed in §5.3.2.

In larger words the final two enclitics create a PWord clitic. One has two assume that one clitic can serve as the host two another clitic to its left.

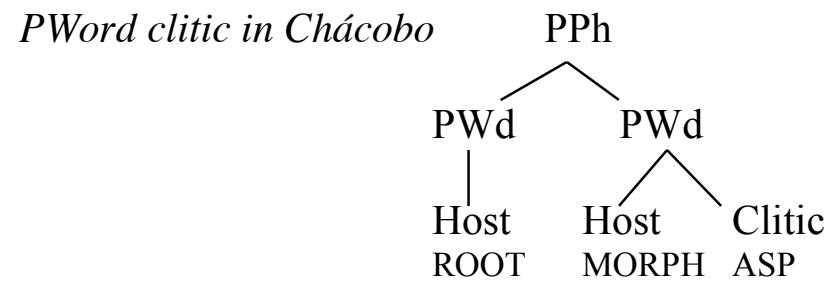

\subsubsection{H-tone Epenthesis in PWd]PPh}

If the right-most $\mathrm{PWd}$ does not contain an underlying $\mathrm{H}$ tone, it is inserted through $\mathrm{H}$-Tone Epenthesis.

(50) H-TONE EPENTHESIS ON PENULTIMATE SYLLABLE

tsáyà-tìkì-kàrá-kì

see-AGAIN-DUB-CMPL

'He probably saw him again.'

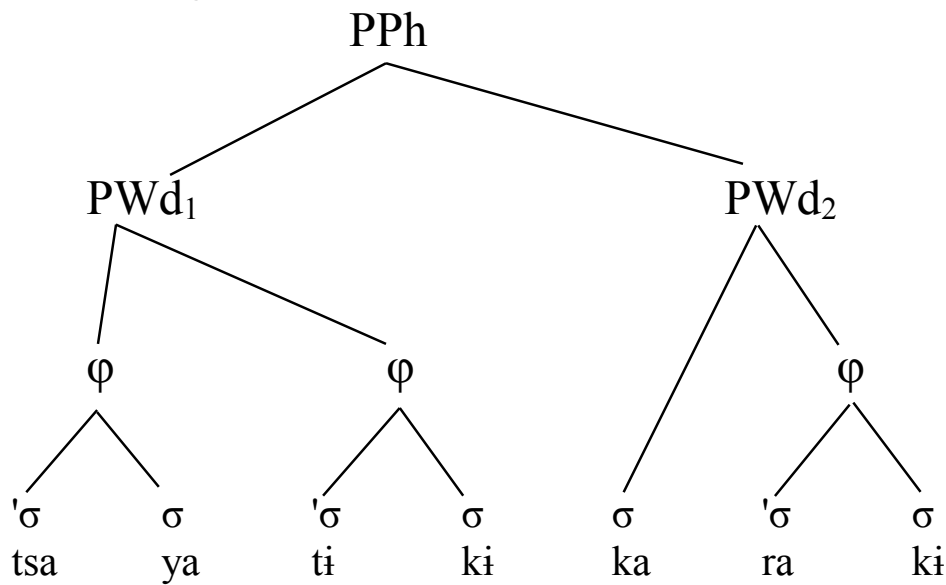

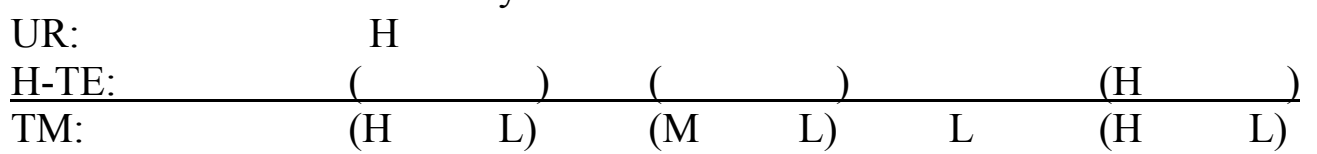

In (50) $\mathrm{H}$-tone epenthesis applies to $\mathrm{PWd}_{2}$ in order to satisfy a condition of $\mathrm{PPh}$ that its rightmost $\mathrm{PWd}$ must contain an $\mathrm{H}$ tone. 


\subsubsection{Metrical lapses in PPh}

We saw that when there was an uneven amount of syllables in the final two morphemes there was an LL metrical lapse. If PWd is constructed on the right edge of the PPh with these final two morphemes we can account for the conditions under which there is an LL metrical lapse in the verb complex. First consider the case where there is no metrical lapse- where there is an even number of syllables in the right-most PWd. This is given in (51).

(52) in contrast has an uneven number of syllables in its right-most PWd. The LL metrical lapse is the result of restarting the parsing of default right-to-left trochees after the right-most PWd. ${ }^{16}$

EVEN NUMBER OF SYLLABLES IN PWd $]_{\mathrm{PPh}}=$ NO METRICAL LAPSE

$h \bar{a} b \grave{a}-t \bar{t} k \grave{t}-b a \bar{P}$ ìná-kì

run-AGAIN-ALLDAY-INCL

'He is running all day again.'

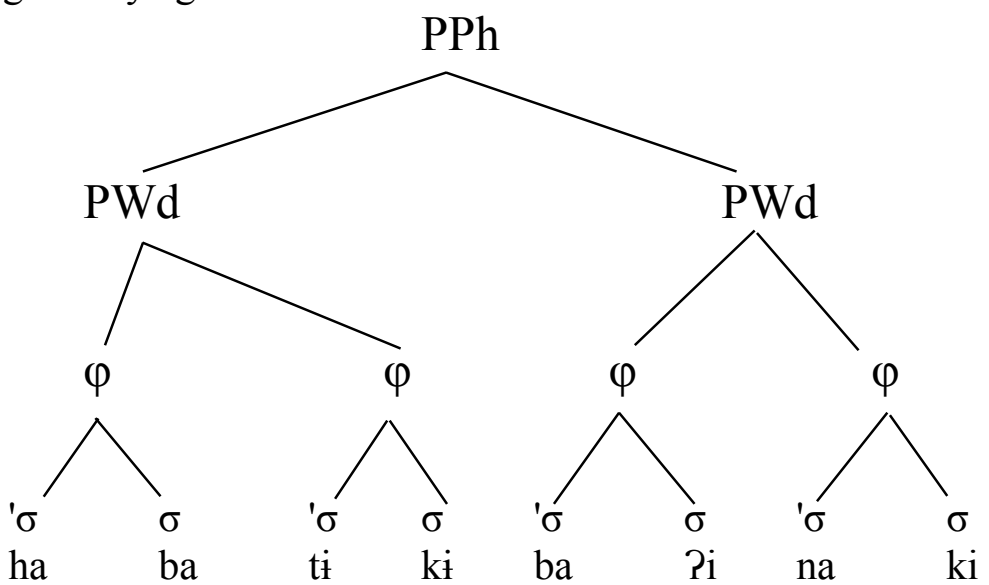

UR:

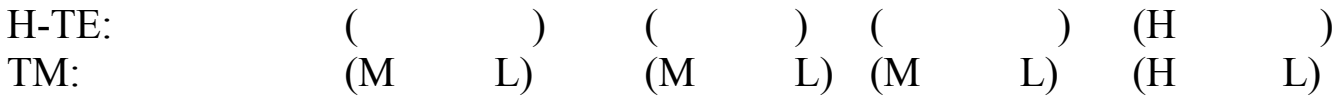

\footnotetext{
${ }^{16}$ An alternative analysis that was proposed at the Berkeley Linguistics Society conference was to stipulate that obligatory H-tone epenthesis occurs in a three syllable window right-aligned to the verb complex. This is discussed in $\S 5.5$.
} 
UNEVEN NUMBER OF SYLLABLES IN PWd $]_{\mathrm{PPh}}=$ METRICAL LAPSE

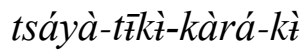

see-AGAIN-DUB-CMPL

'He probably saw him again.'

UR:

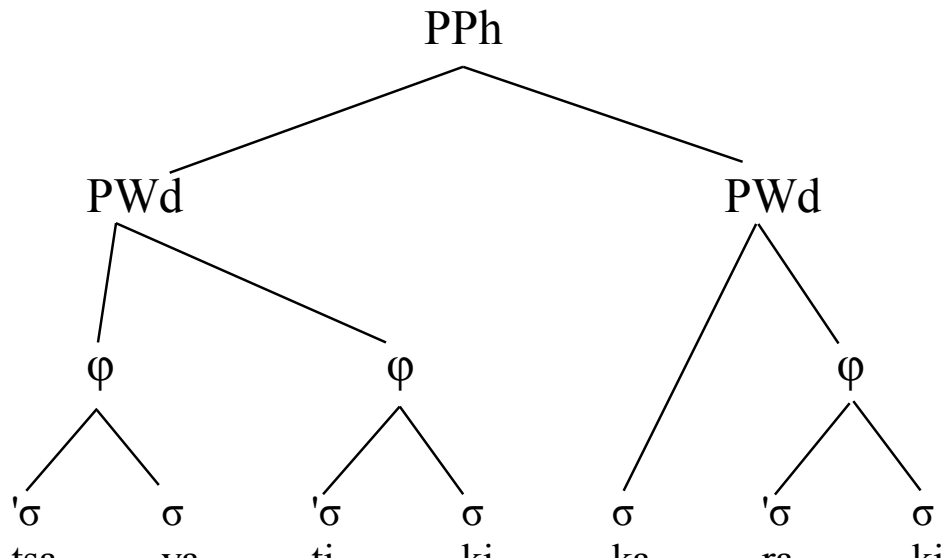

H-TE:

$\mathrm{H}$

TM:

$$
\text { ( }
$$

ya ti

$\mathrm{ki} \quad \mathrm{ka}$

ra ki

The next section discusses cases where the H-tone epenthesis fails to apply.

\subsection{Exceptions to H-tone epenthesis in PWd: Low tones and Free clitics}

\subsubsection{H-TE does not apply when $H$ tone is already in PWd]PPh}

$\mathrm{H}-\mathrm{TE}$ only occurs in order to satisfy the requirement that the right-most $\mathrm{PWd}$ have an $\mathrm{H}$ tone. If an $\mathrm{H}$ tone is present in $\mathrm{PWd}]_{\mathrm{PPh}}$ underlyingly, culminative and obligatory $\mathrm{H}$ tone is already satisfied within the $\mathrm{PWd}]_{\mathrm{PPh}}$.

(53) H-TONE MORPHEMES IN PWd ]PPh

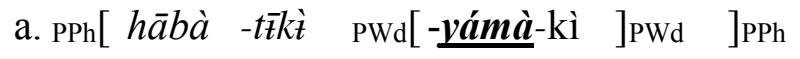

run -AGAIN -NEG -INCL

'He doesn't run again.'

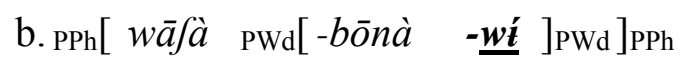

steer -GO.TR -IMPER2

'Steer (the boat), while moving!' 


\subsubsection{H-TE does not apply when penultimate morpheme is an L-tone in PWd]PPh}

-tsa NOW is an L-tone morpheme. When it occurs in penultimate position H-TE is blocked in $\mathrm{PWd}]_{\mathrm{PPh}}$. One way of accounting for this is by assuming, as is done in $\S 5.1$, that morphemes that block $\mathrm{H}$-Tone epenthesis do so because they are already specified underlyingly as a having an $\mathrm{L}$ tone in the position where the HTE would apply (the penultimate syllable). On this analysis Ltone morphemes surface with an M pitch when they are in a metrically strong position. This could be the phonetic output of a metrically strong low tone. This phonology-phonetic interfacing rule is given in (55).

L-TONE MORPHEME IN PWd $]_{\mathrm{PPh}}=$ L TONE ON H-TONE SYLLABLE tsáyà-yámà-tsāa $k \grave{t}$ see-NEG-NOW-CMPL

'He did not see him at that moment.'

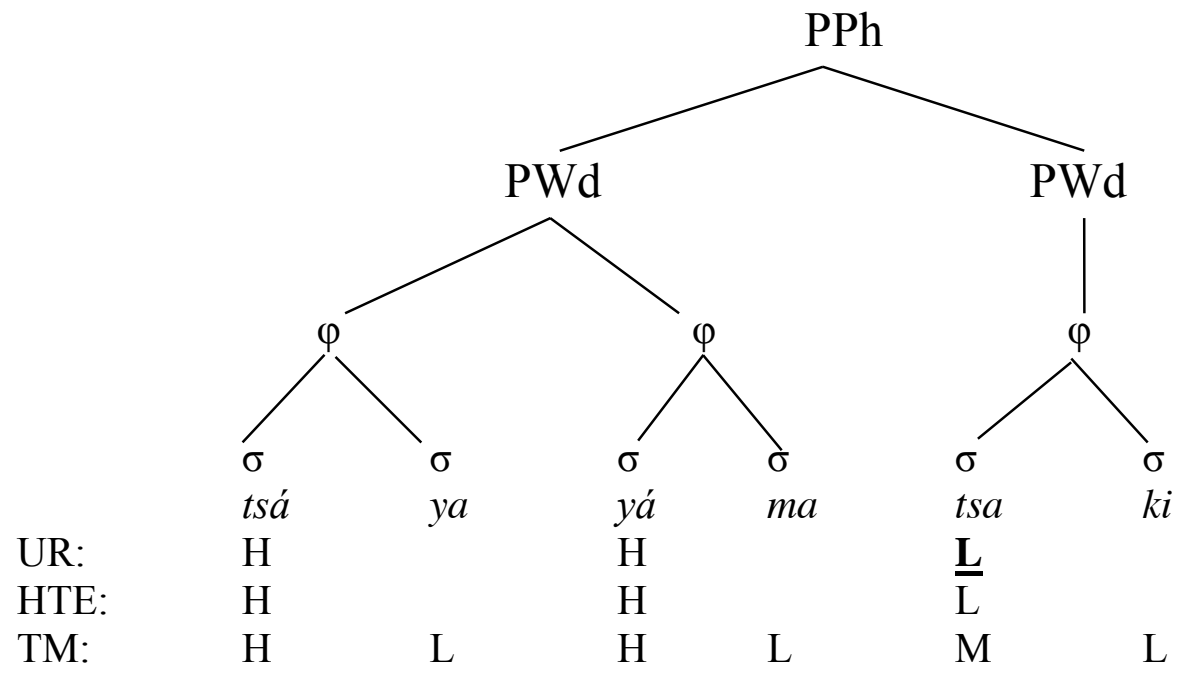

(55) $L-^{\prime} \sigma \rightarrow M$ Spell out Rule: An L tone on an H-Tone syllable surfaces as an M tone.

In other words the presence of an underlying $\mathrm{L}$ tone (underlined in the example above) blocks the insertion of an H-tone. H-tone epenthesis does not apply to metrically weak syllables ( $m a$ or $k i$ in the example above) (see §3). A morpheme that is marked with an L-tone underlyingly surfaces with an M tone. ${ }^{17}$

\subsubsection{H-TE does not apply when no right-aligned PWd is constructed}

Based on the analysis presented thus far there are two circumstances in which a PWd is constructed. One is over a stem, the other is based on the final two enclitics of the verb complex.

\footnotetext{
${ }^{17}$ At this point I think it is important to point out that acoustic phonetic studies have not been done. It is possible that other correlates to metrical prominence besides pitch are important here that I was not able to hear.
} 
There is no H-TE when no PWd can be constructed on the right edge of the verb complex. Only the final aspectual marker is actually obligatory (cf. Figure 1). If this monosyllabic enclitic is stranded apart from any other verbal material, it simply attaches to any element to its left with no effect on tonal or metrical patterns. It is prosodized as a free clitic rather than undergoing vowelepenthesis so that it can be inside a PWd.

(56) NO PWd ]PPh CONSTRUCTED, LACK OF PHONOLOGICAL MATERIAL

kaa honi=ki

go $\operatorname{man}=\mathrm{CMPL}$

'The man left.'

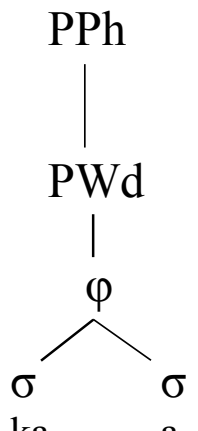

UR:

ka a

HTE: $\quad \mathrm{H}$

TM:

$$
\mathrm{H} \quad \mathrm{L}
$$

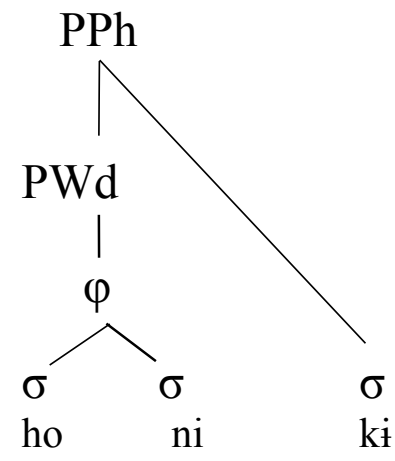

The behavior of the ASP marker contrasts with that of the stem which adds a vowel to meet requirements for prosodic word. The root must be under a PWd and vowel epenthesis saves a monosyllabic root when it is stranded in the split construction. This is not true of the final aspect marker which prosodizes as a free clitic.

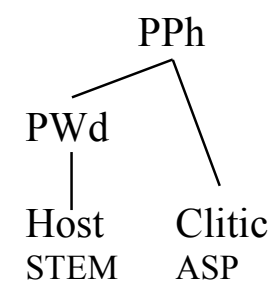

\subsection{A Stress Window for $\mathbf{H}$ tone?}

An alternative analysis to the construction of a right edge PWd with functional morphemes would be to assume that H-tone is mapped onto a stress that occurs in a three syllable window of the right edge of the verb complex. A two or three syllable stress window is well-attested typologically (cf. Kager 2012). 
The first problem with such an analysis is that by itself it would fail to account for the metrical lapse described in $\S 4.3 .3$. However, an alternative way of accounting for the metrical lapse is by assuming that default trochees are parsed from left to right outside of a three syllable window within PWd. Consider the following example which contains only toneless morphemes.

$$
\begin{gathered}
\text { a. [ haba-kara-tiki-ki ]PWd } \\
\text { run-DUB-AGAIN-CMPL }
\end{gathered}
$$

b. [ haba-kara-tit $(k \dot{t}-k \dot{t})] \mathrm{PWd}$

(3 syllable window for trochaic foot on right edge)

$\rightarrow \mathrm{S}$ W $\mathrm{S}$ W $\mathrm{S}$ W

c. $[(h a b a)-(k a r a)-t \dot{t}(k \dot{t}-k \dot{t})]_{\mathrm{PWd}} \quad$ (left-to-right parsing in the rest of the verb complex)
$\begin{array}{llllll}\mathrm{S} & \mathrm{W} & \mathrm{S} & \mathrm{W} & \mathrm{S} & \mathrm{w}\end{array}$

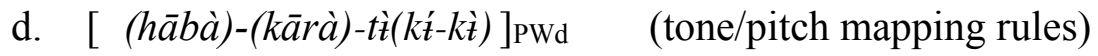

The parsing algorithm sketched above that contains parsing from left-to-right demonstrates that a right edge PWd is not necessary for capturing either the fact that the metrical lapse occurs, or the fact that final $\mathrm{H}$ tone is obligatory in the last two syllables. The entire verb complex is composed of one $\mathrm{PWd}$ which requires an $\mathrm{H}$ tone. Prima facie this analysis seems simpler than the one proposed above because the obligatory and culminative character of $\mathrm{H}$ tone is defined in $\mathrm{PWd}$ rather than the right-most PWd in PPh. Furthermore, this analysis is more in line with the analysis of prosodic clitics presented in Selkirk (1996) since it will not entail that function words can serve as hosts.

The stress-window analysis has some problems, however. First one needs to construct a right edge PWd in the split construction anyway. H-tone epenthesis applies in the stranded clitic material as in the following example. The marker clitic -tiki- AGAIN is a toneless morpheme. In (59) it surfaces with an $\mathrm{H}$ tone, the penultimate syllable of the verbal pieces on the right side of the split verb construction.

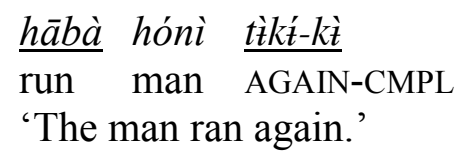

In order to continue maintaining the stress window analysis given in (58) one would have to assume that the PWd is discontinuous, an impossibility in all theories of prosodic phonology that I am aware of.

The other problem with the stress window analysis is that it would run counter to typological work in word prosody (Hyman 2006, 2009) that culminativity and obligatoriness are properties 
of stress systems. If the PWd spans over the entire verb complex and we assume that $\mathrm{H}$ tone is a marker of stress then culminativity is not a property of PWd contra Hyman $(2006,2009)$.

\section{Discussion and Conclusion}

This paper's main focus has been to give a description of the prosodic structure of the verb in Chácobo. The study demonstrates that different prosodic classes of morphemes need to be acknowledged to account for the prosodic behavior of verbal morphemes, including underlying L-tones, not present in other Panoan languages. In addition to this, I provided an analysis of the prosodization of clitics in the language based on the typology of prosodic clitics given in Selkirk (1996) and Anderson (2005). Instead of the PWd being constructed over the verb complex, it is constructed over various subdomains of it post-lexically. The split construction requires that some morphological clitics serve as prosodic hosts. The construction of a right edge $\mathrm{PWd}$ in $\mathrm{PPh}$ accounts is necessary in order to describe PWd construction in the split construction where aspectual and other material are stranded from the stem. But the construction of the right edge PWd also accounts for the distribution of $\mathrm{H}$ tones in the verb complex and LL metrical lapses.

In the analysis presented here, I have relaxed the requirement that clitics are prosodically deficient in a sense, since some functional elements need to serve as the host of the aspectual marker in the split construction. The difference between lexical items and prosodic word clitics is that in the latter case prosodic word construction is post-lexical (cf. discussion in Anderson 2005). Some readers may be alarmed at this move since it implies that learners of the language will have a more difficult time inferring lexical/functional status from prosodic structure. Perhaps it is not surprising however, and reflects the fact that the language is in a nascent state of synthesization. I also point out that many morphemes in fact $d o$ have an ambiguous status as lexical or functional elements. For instance kas- DES can serve as a desiderative marker modifying a main verb, or be inflected and modified as a main verb itself meaning 'want'.

To a certain extent the current study has been limited by the nascent state of knowledge in both the syntax and prosody of Chácobo. A more detailed study of prosody in Chácobo would contextualize the construction of prosodic domains with respect to all other prosodic phenomena of the language (truncation (Córdoba et al. 2012), tone sandhi (Iggesen 2006, 2007), suprasegmental case marking (Valenzuela \& Iggesen 2007)). In order to really assess the importance of Chácobo for studies in syntax-phonology interfacing one would also need to give a more formalized analysis of syntax and morphology than has been given here (Elordieta 2008 for a review of approaches to the syntax-phonology interface). Another problem with the current study is that the suprasegmental data are based almost entirely on impressionistic transcriptions. Instrumental phonetic investigation might reveal important details in the tonal and metrical system here that were missed by the author. 
Aikhenvald, Alexandra. 2012. Languages of the Amazon. Oxford: Oxford University Press. Anderson, Stephen R. 2005. Aspects of the Theory of Clitics. Oxford: Oxford University Press. Bloomfield, Leonard. 1933. Language. New York: Holt.

Boas, Franz. 1911. Introduction. In Franz Boas, ed., Handbook of American Indian languages, part 1 (Bureau of American Ethnology Bulletin 40). pp. 1-83. Washington: Government Printing Office.

Córdoba, Lorena, Pilar Valenzuela and Diego Villar. 2012. Pano meridional. In Mily Crevels and Pieter Muysken, eds., Lenguas de Bolivia: Tomo II Amazonía. pp. 27-70. Plural: La Paz. Córdoba, Lorena and Oliver Iggesen.

de Lacy, Paul. 1999. Tone and Prominence. Rutgers Optimality Archive.

de Lacy, Paul. 2002. The interaction of tone and stress in Optimality Theory. Phonology 19. 1-32

Dixon, R. M. W. and Alexandra Aikhenvald. 2002. Word: A typological framework. In R. M.

W. Dixon and Alexandra Aikhenvald, eds., Word: A Cross-linguistic Typology. pp. 1-42.

Cambridge: Cambridge University Press.

Elias-Ulloa, Jose. E. 2006. Theoretical Aspects of Panoan Metrical Phonology: Disyllabic footing and contextual syllable weight. PhD dissertation, New Jersey State University.

Elias-Ulloa, Jose. 2011. Una documentación acústica de la lengua Shipibo-Konibo (Pano) (Con bosquejo fonológico). Perú: Fondo Editorial.

Elordieta, Gorka. 2008. An Overview of Theories of the Syntax-Phonology Interface. ASJUA XLII(1). 209-286.

Fleck, David. 2003. A Grammar of Matses. PhD dissertation, Rice University

Fleck, David. 2006. Body-part Prefixes in Matses: Derivation or Noun Incorporation?

International Journal of American Linguistics, Vol 72(1): 59-96.

Fleck, David. 2013. Panoan Languages and Linguistics. American Museum Natural History Anthropological Papers, Number 99. American Museum of Natural History Scientific Publications.

González, Carolina. in prep. Tipología de los sistemas métricos de veinticinco lenguas pano. In Antoine Guillaume and Pilar Valenzuela, eds., Estudios pano y takana: fonología, morfología y sintaxis. Amérindia.

Guillaume, Antoine. 2010. Lecture 3: Verb structure and verbal categories. Areal Course: Amazonian Languages, 3L International Summer School on Language Documentation and Description, Leiden University, 5-9 July 2010.

Haspelmath, Martin. 2011. The indeterminancy of word segmentation and the nature of morphology and syntax. Folia Linguistica 45/1. 31-80.

Hayes, Bruce. 1995. Metrical Stress Theory. Chicago: Chicago University Press.

Hockett, Charles F. 1958. A course in modern linguistics. New York: MacMillan.

Hyman, Larry. 2006. Word-prosodic typology. Phonology 23. 225-257.

Hyman, Larry. 2009. How (not) to do phonology typology: the case of pitch accent. Language Sciences 31. 213-238.

Iggesen, Oliver. 2006. Case Morphosyntax in Chacobo: Multiple Alignment Splits and Suprasegmental Marking. ms, RCLT.

Iggesen, Oliver. 2007. The great killjoy of Chacobo case marking: How tone sandhi undermines suprasegmental morphology. ms, RCLT. 
Kager, René. 2012. Stress in windows: Language typology and factorial typology. Lingua 122: 1454-1493.

Loos, Eugene. 1999. Pano. In The Amazonian Languages. In Alexandra Aikhenvald and R. M. W. Dixon, eds., pp. 227-251. Oxford: Oxford University Press.

Mithun, Marianna. 1984. The evolution of noun incorporation. Language 60: 847-894.

Mugdan, Joachim. 1994. Morphological units. In R. E. Asher, ed., The encyclopedia of language and linguistics. pp. 2543-2553. Oxford: Pergamon Press.

Nespor, Marina and Irene Vogel. 2007[1986]. Prosodic Phonology. Amsterdam: Mouton de Gruyter.

Payne, Doris, L. 1990. Morphological Characteristics of Lowland South American Languages. In Doris Payne, ed., Amazonian Linguistics. pp. 213-243. Austin: University of Texas at Austin Press.

Prost, Gilbert. 1960. Fonemas de la lengua chácobo. Notas Lingüísticas de Bolivia. La Paz.

Ortiz, Gere and Adam J. Tallman. 2012. El desarollo del alfabeto pacahuara, para el ministerio de educación. ms, Riberalta, Bolivia.

Russell, Kevin. 1998. What's With all These Long Words Anyway? MIT Occasional Papers in Linguistics 17: 119-130. Cambridge: The MIT Press.

Russell, Kevin. 2000. The word in two polysynthetic languages. Studies in the phonological word. T.A. Hall, U. Kleinhenz, eds. Amsterdam: John Benjamins.

Selkirk, Elizabeth. 1984. Phonology and Syntax: The Relation between Sound and Structure. Cambridge: The MIT Press.

Selkirk, Elizabeth. 1986. On derived domains in sentence phonology. Phonology Yearbook 3: 371-405.

Selkirk, Elizabeth. 1996. The prosodic structure of function words. In James L. Morgan \& Katherine Demuth, eds., Signal to Syntax: Bootstrapping from Speech to Grammar in Early Acquisition. pp. 187-225. New Jersey: Lawrence Erlbaum Associates Publishers.

Shell, Olive. 1975. Estudios Panos III: las lenguas pano y su reconstrucción. Lima: Instituto Lingüístico de Verano.

Tallman, Adam. J. in prepa. A metrical analysis of nouns in Chácobo (Pano). In Antoine Guillaume and Pilar Valenzuela, eds., Estudios pano y takana: fonología, morfología y sintaxis. Amérindia.

Tallman, Adam. J. In prepb. The prosody of clitics in the Chácobo verb. ms, PhD Qualifying paper for UT Austin.

Valenzuela, Pilar. 2009. Case marking in Chácobo in Panoan perspective. ms, Chapman University.

Valenzuela, Pilar. \& Oliver A. Iggesen. 2007. El desarrollo de un marcador suprasegmental en Chácobo (Pano). Andrés Romero-Figueroa, Ana Fernández Garay \& Ángel Corbera Mori, eds., Lenguas Indígenas de América del Sur: Estudio descriptivo-tipológicos y sus contribuciones para la lingüística teórica. pp. 187-199. Caracas: Publicaciones Universidad Católica Andrés Bello.

Zariquiey, Roberto. 2011. A Grammar of Kashibo-Kakataibo. PhD dissertation, RCLT.

Zingg, Philippe. 1998. Diccionario Chacobo-Castellano. La Paz: Viceministerio d Educación Inicial, primaria y Secundaria.

Zwicky, Arnold and Geoffrey Pullum. 1983. Cliticization vs. Inflection: English $n$ 't. Language 59: 502-513. 
